\title{
HER MENTAL HEALTH DURING COVID-19: \\ FAMILY A STRESSOR OR A DE-STRESSOR
}

Anubhuti SINGH ${ }^{1}$

\begin{abstract}
The world witnessed very troubled times in the past year and there seems to be not much respite in the coming days. The COVID-19 pandemic is viewed as one of the most disturbing calamities by many countries, their governments and the people alike. Women have been found to be impacted more by the pandemic due to financial insecurities and increased workload at all fronts. Increased time spent with the family was seen as a boon by some and a downside by some others. The present study is an attempt to gain a perspective on whether family is perceived as a stressor or a de-stressor by Indian women during the current pandemic. Findings of the study conducted on women in India suggest that they found solace with their family during this period.
\end{abstract}

Keywords: mental health, family support, domestic violence, COVID-19 pandemic, stress DOI: $10.24818 / \mathrm{SYN} / 2021 / 17 / 2.03$

\section{Background}

Looking at the reports coming from throughout the world, one may assert that the year just gone by (2020) has greatly impacted the world. The happenings have put tremendous pressure not only physically but also mentally, and we keep contemplating and transitioning between the mundane chores and activities on the one hand and the bigger quests for survival and existence on the other. The present living population has never witnessed and hopefully will never again be caught in such widespread, ubiquitous and yet common to all calamity as the COVID-19 pandemic.

The tragedy has hit all alike be it the elderly or the young, the bread earners or the home makers, the patients or the doctors, those who succumbed to the virus or those who are left behind, and has in a way levelled the ground for the haves and the have-nots. The building up of mental pressure has tremendously increased the instances of mental health issues among all during the last year. According to a study by the World Health Organization, during the pandemic the cases of deteriorating mental health have been on the rise and the pandemic has even caused disruption in the mental health care services in more than $93 \%$ of the countries surveyed adding to the vows (Mathur, 2020). According to health experts the urge to be constantly updated on the happenings related with the pandemic keeps our

1 Anubhuti Singh, KES Shroff College of Arts and Commerce, Mumbai, India, anubhuti1singh2@gmail.com 
mind on toes and keeps us in a constant reminder of the danger very probable for us, too. This has increased the amount of stress and anxiety among all. When it comes to mental health, there has always been a gender gap prevalent against women and during the pandemic this gap is felt to be widening (Sabharwal, 2020). The change has occurred in everyone's life but the disruption in the daily routines has been most obvious among the women folk. Epidemics and pandemics impact lives adversely and the trauma has been found to be more in the lives of women. More women tend to lose their jobs than men, responsibilities increase many fold in the household be it in the form of taking care of the children or the elderly and the entire family put in confined spaces for long periods of time due to lockdown leading to increased instances of domestic violence (Singhania, 2020). The family, being one of the most important institutions determining the social and mental well being of a person, plays a crucial role in influencing mental health and stability. The present study is an attempt to find out whether family has been a support or a stressor for the women of the house during the pandemic.

\section{Literature Review}

There have been a number of studies conducted on the implications of the COVID-19 pandemic in the last few months since the time the world is grappling with it.

A study conducted in the Alberta State of Canada on the impact of the pandemic on the physical and mental health of mothers, pre-partum and post-partum, suggests that the pandemic has impacted them adversely due to stress and anxiety (Davenport, Meyer, Meah \& Morgan, 2020). At the same time, reduced physical activity due to restrictions such as lockdown, has further aggravated the mental health issues. Although the study was based in Canada, it referred to stress among mothers during the period of the pandemic in general.

Another review study on gender-based violence during the COVID-19 pandemic stated that there has been an alarming increase in violence against women at home during the pandemic (Mittal \& Singh, 2020). The article also pointed out the factors that led to the surge in gender-based violence. It has been attributed to more alcohol consumption and financial insecurities besides confinement at home.

A study on maternal health in India during the pandemic reiterates on the physical and mental health issues of mothers and also of migrant female workers (Jungari, 2020). The article emphasizes the need of clearer policies and steps taken by the government for migrant workers so that the uncertainty about their future, which is a very major cause of anxiety and depression during the pandemic, is reduced.

Another study on issues related to women's mental health and domestic violence in India suggests the patriarchal Indian mental block to be a significant reason for the increased cases of domestic violence during the lockdown (Mansharamani \& Kishore, 2021). This was further intensified by the lack of existing social support 
of extended families and friends for the woman of the house that could have been of help in times of distress.

In an article regarding the ways to help women come out of mental distress during the pandemic, a number of initiatives were suggested that may help females bring their lives back to near normal (Chatterjee, 2021). The suggestions include providing financial support through cooperatives, providing insurance related to the pandemic and even giving a platform to share their vows and views with other women.

A report on the perspectives of women facing domestic violence seeking institutional support for the same highlights a few interesting points (Mahapatro, et al., 2021). The article states that the men of the house during lockdown were less abusive as they got to spend more time with the family. Lesser alcohol consumption, more spiritual inclination due to the fear of the pandemic and other challenges diverted their minds and led to decrease the instances of abusing their wives. At the same time those facing domestic violence found it very challenging to seek support while staying with their abuser.

A research study on the possible impact of the pandemic on the mental health of different set of populations such as the elderly, children and adolescents, pregnant women and health care workers very categorically suggests that misinformation or lack of information and uncertainty about dealing with the virus is adding on to the increased levels of stress and anxiety among all (Dalal, Roy, Choudhary, Kar \& Tripathi, 2020). There is dire need for constant communication of government authorities with people regarding the spread and containment of the pandemic as and when correct and reliable information is obtained.

Although there have been a number of studies citing the increase in the stress levels among women due to instances of domestic violence, pressures to take care of the elderly and the children in the family and increased household chores, there is not much thought given to the support that the primary social institution called family has provided to the women during these testing times. The present study is an attempt to find out whether the family has contributed to or reduced the stress faced by females during the pandemic.

\section{Scope of the Study}

As the study is a reflection of the impact the pandemic had on the mental health of females in Indian context, the population considered is restricted to females residing in various cities pan India. There is no restriction on the geographical area covered within the country. Data has been collected in the months of January through March 2021 and thus the responses pertain to the period in India when the first wave of COVID-19 pandemic had subsided and the second wave had not yet 
begun. Uncertainty about the extent to which the pandemic would continue in relation to time and impact was still high. The study is limited to finding out the role of the family for the females during the time of the pandemic as in whether they received help and comfort with their immediate family or did the family responsibilities add to the woes of the female of the house.

\section{Objectives of the Study}

The objectives of the study are:

1. To find out if the last year was perceived as more stressful for females

2. To assess the role played by the family for a female in dealing with stress

\section{Research Methodology}

The study is conducted in India by taking the responses from females of various age groups, educational, marital and employment status and income groups. No intended categories for age groups are created before collecting the data. Similarly for educational, employment and marital status too, no quota was intentionally decided. The Google form questionnaire is circulated online through platforms such as WhatsApp and emails. Thus convenient sample comprising 110 respondents constitutes the basis of the study. The questions in the questionnaire are varied such as enquiring whether the respondent or any of her family members tested positive for COVID-19, ranking the factors that the respondent considers important for inducing and reducing stress during the period of the pandemic and whether she feels that her family members help her in reducing her anxiety and stress during the pandemic. The researcher later classified the factors reducing and leading to stress into those that were 'due to family' and the rest as 'other than family'. For example, among factors in the family leading to stress are anger issues with family members, taking care of the elderly, domestic violence and the like; whereas those other than the family include fear of contracting the virus, job loss, work from home, monotony due to restrictions in movement and others. Considering the factors that reduce stress, family contributions include spending quality time with family members, getting their help in the household chores and sharing one's thoughts with others in the family; and factors other than the family include watching television or other modes of entertainment, pursuing hobbies, taking rest for longer hours and the like.

\section{Data Analysis and Discussion}

SYNERGY volume 17 , no. $2 / 2021$ 
Data were collected from 110 female respondents through a questionnaire created with Google forms circulated online through WhatsApp and emails. The following figures help to understand the distribution of the sample.

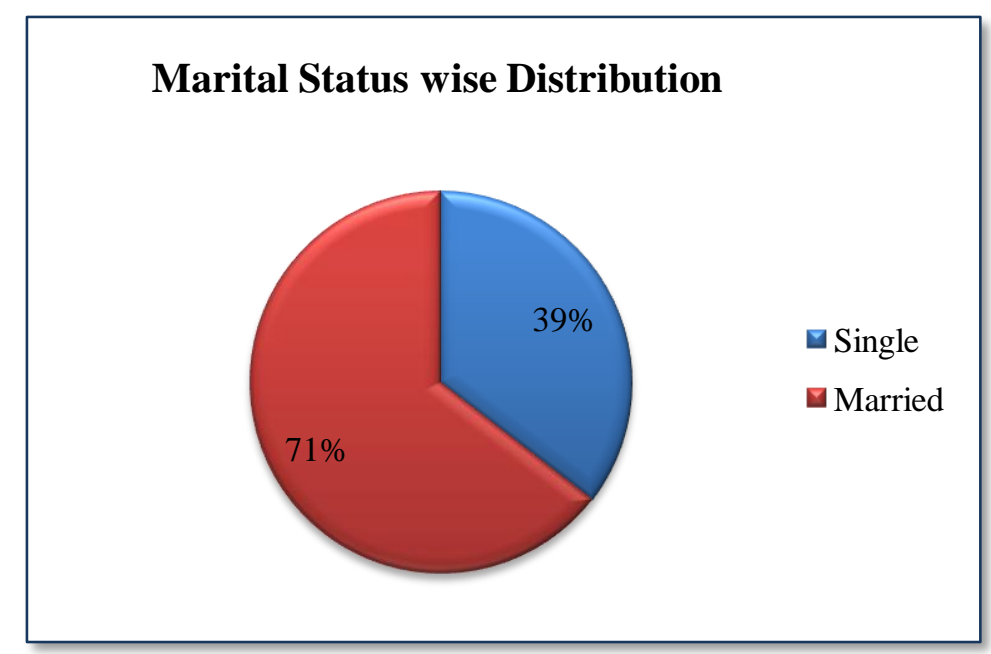

Fig 1. Marital Status wise distribution of sample

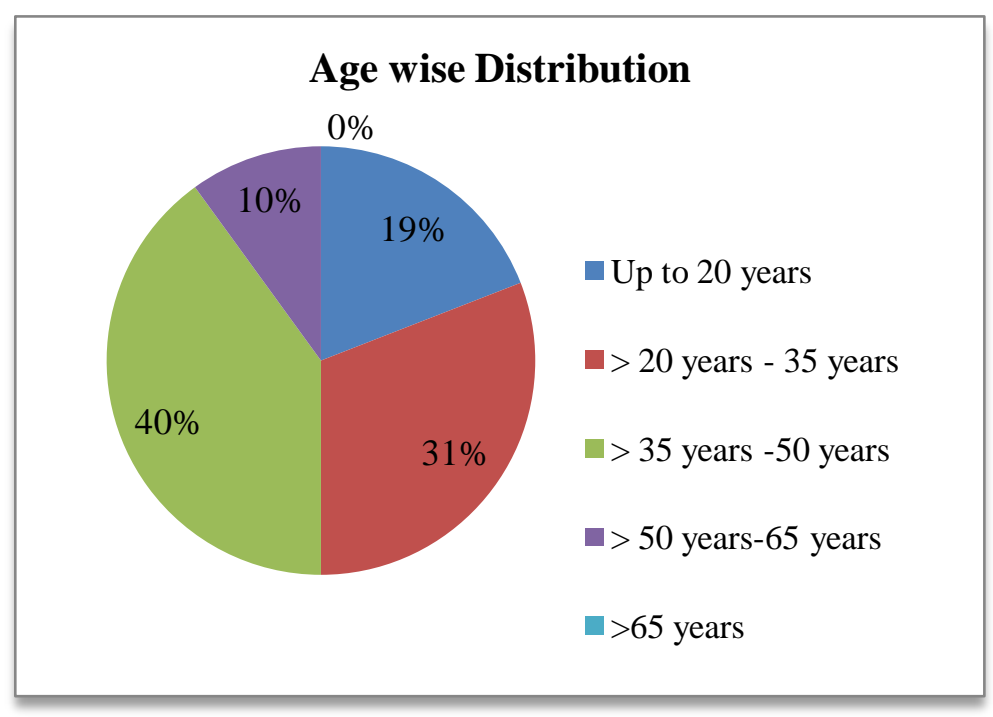

Fig 2. Age wise distribution of sample 


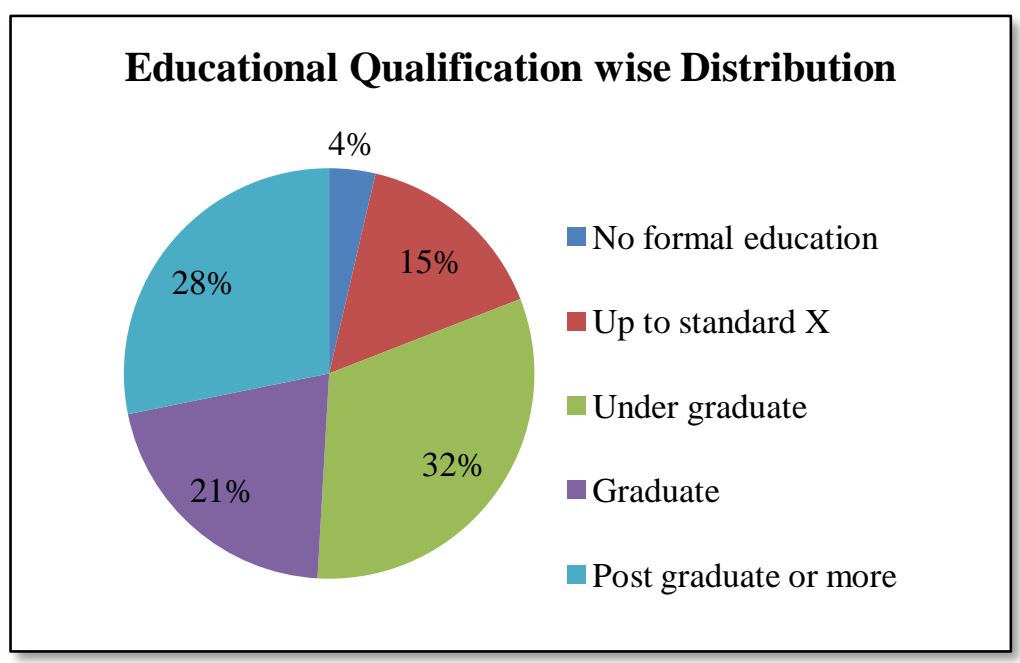

Fig 3. Educational status wise sample distribution

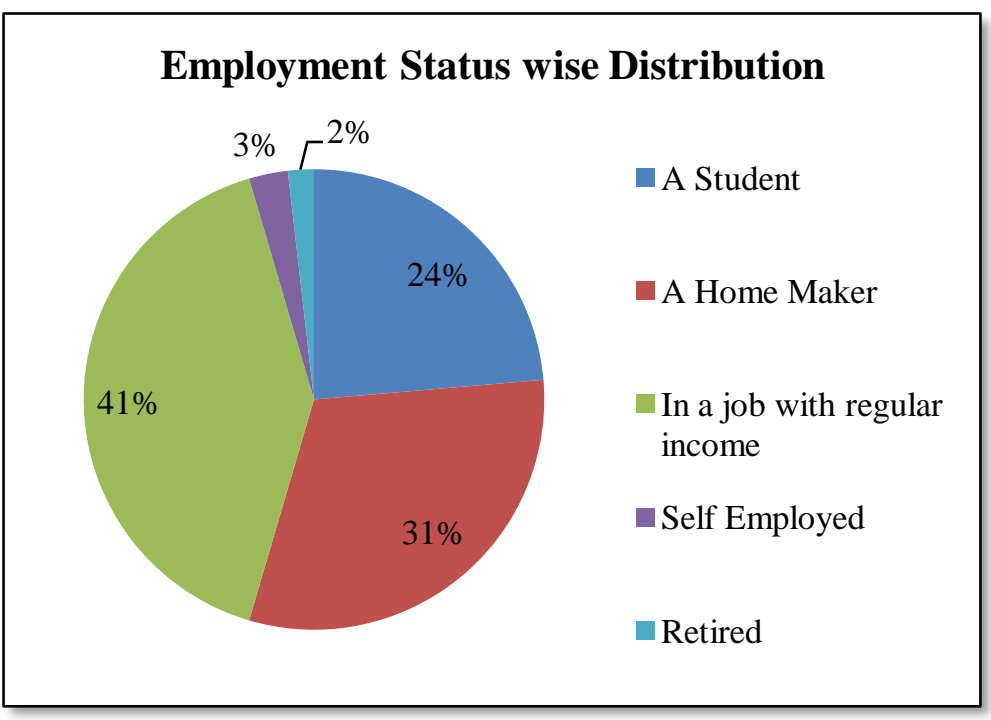

Fig 4. Employment status wise sample distribution

The distribution of the sample shows that females of almost all age groups except for those above the age of 65 years are a part of the sample (Figure 1). The majority (71\%) are married (Figure 2) and also represent females having varied educational qualifications (Figure 3). Most respondents are salaried (41\%), are home-makers $(31 \%)$ or are students (24\%) (Figure 4). Thus, the sample represents a heterogeneous mix of respondents. 
Of all the respondents, $16.4 \%$ had tested positive for the Corona virus in the past one year and one or more family members got infected with the virus in the case of $45.5 \%$ respondents. $82 \%$ of the respondents accepted feeling more stressful in the past one year than before. By asking the question mentioned in Table 1, the researcher tried to find out whether there existed any association between the feeling of more stress in the past one year in relation to before with various factors such as age, educational qualifications, employment status, marital status and family income.

\begin{tabular}{|l|l|l|l|l|}
\hline $\begin{array}{c}\text { Did you experience more stress in } \\
\text { the past one year than before? } \\
\text { [Yes][No] }\end{array}$ & $\begin{array}{c}\text { Chi Square } \\
\text { test statistic }\end{array}$ & df & p-value & $\begin{array}{c}\text { Association } \\
\text { found }\end{array}$ \\
\hline Age & 4.33 & 4 & 0.36 & No \\
\hline Educational Qualification & 7.65 & 4 & 0.11 & No \\
\hline Employment Status & 4.68 & 4 & 0.32 & No \\
\hline Marital Status & 0.97 & 1 & 0.32 & No \\
\hline Income status & 11.91 & 9 & 0.22 & No \\
\hline
\end{tabular}

Table 1. Association of variables with perception of stress

As seen in table 1, various demographic factors were not found to have any association with the perception of more stress in the past one year.

The respondents were asked if the family helped them in reducing stress during the period. It was also analyzed if there exists any association in the perception of family reducing stress with various factors. The results of the analysis are presented in Table 2.

\begin{tabular}{|l|l|l|l|l|}
\hline $\begin{array}{c}\text { Were your family members helpful } \\
\text { in reducing your stress levels during } \\
\text { the pandemic?[Yes][No] }\end{array}$ & $\begin{array}{c}\text { Chi Square } \\
\text { test } \\
\text { statistic }\end{array}$ & df & p-value & $\begin{array}{c}\text { Association } \\
\text { found }\end{array}$ \\
\hline Age & 3.13 & 4 & 0.17 & No \\
\hline Educational Qualification & 0.07 & 4 & 0.07 & No \\
\hline Employment Status & 4.93 & 4 & 0.29 & No \\
\hline Marital Status & 27.57 & 1 & $\begin{array}{l}1.51 \quad \text { E- } \\
07\end{array}$ & Yes \\
\hline Income status & 4.75 & 9 & 0.86 & No \\
\hline
\end{tabular}

Table 2. Association of variables with perception of family reducing stress

The $\phi$ (Phi) Coefficient for marital status with perception of family reducing stress was 0.50 suggesting that there is a strong positive relationship between marital status and the perception that family reduced stress during the period of Covid-19 pandemic. On calculating the $\lambda$ (Lambda) Coefficient value considering 'Marital Status' as the Independent variable and 'perception of family as a de-stressor' as 
the dependent variable, it came out to be 0.3421 which means that in $34 \%$ of cases it is possible to predict the perception of family reducing stress during pandemic if the marital status is known.

\begin{tabular}{|l|l|l|l|l|l|}
\hline $\begin{array}{c}\text { Reasons for stress } \\
\text { (not due to family) }\end{array}$ & $\begin{array}{l}\text { Extremely } \\
\text { Important }\end{array}$ & $\begin{array}{c}\text { Very } \\
\text { Important }\end{array}$ & Neutral & $\begin{array}{l}\text { Somewhat } \\
\text { Important }\end{array}$ & $\begin{array}{l}\text { Not at all } \\
\text { Important }\end{array}$ \\
\hline COVID in the family & $18 \%$ & $7 \%$ & $15 \%$ & $15 \%$ & $45 \%$ \\
\hline Fear of contracting the virus & $30 \%$ & $15 \%$ & $22 \%$ & $15 \%$ & $18 \%$ \\
\hline $\begin{array}{l}\text { Job loss/Business loss affecting } \\
\text { regular income }\end{array}$ & $22 \%$ & $14 \%$ & $19 \%$ & $15 \%$ & $31 \%$ \\
\hline $\begin{array}{l}\text { Staying at home due to lockdown } \\
\text { leading to boredom }\end{array}$ & $24 \%$ & $15 \%$ & $18 \%$ & $17 \%$ & $25 \%$ \\
\hline $\begin{array}{l}\text { Work from home (myself or other } \\
\text { family members) }\end{array}$ & $21 \%$ & $12 \%$ & $13 \%$ & $18 \%$ & $36 \%$ \\
\hline $\begin{array}{l}\text { Health issues with myself or in } \\
\text { family other than COVID }\end{array}$ & $15 \%$ & $14 \%$ & $16 \%$ & $23 \%$ & $32 \%$ \\
\hline $\begin{array}{l}\text { Monotony due to restrictions in } \\
\text { movement }\end{array}$ & $13 \%$ & $14 \%$ & $25 \%$ & $19 \%$ & $30 \%$ \\
\hline $\begin{array}{l}\text { Balancing personal with } \\
\text { professional life }\end{array}$ & $15 \%$ & $13 \%$ & $17 \%$ & $16 \%$ & $38 \%$ \\
\hline $\begin{array}{l}\text { No house maids } \\
\text { Uncertainty about future }\end{array}$ & $23 \%$ & $10 \%$ & $14 \%$ & $15 \%$ & $39 \%$ \\
\hline Average \% & $25 \%$ & $16 \%$ & $19 \%$ & $15 \%$ & $25 \%$ \\
\hline
\end{tabular}

Table 3. Factors leading to stress during COVID period: Not due to family

\begin{tabular}{|l|l|l|l|l|l|}
\hline \multicolumn{1}{|c|}{$\begin{array}{c}\text { Factors in the family leading } \\
\text { to Stress }\end{array}$} & $\begin{array}{l}\text { Extremely } \\
\text { Important }\end{array}$ & $\begin{array}{c}\text { Very } \\
\text { Important }\end{array}$ & Neutral & $\begin{array}{c}\text { Somewhat } \\
\text { Important }\end{array}$ & $\begin{array}{c}\text { Not at all } \\
\text { Important }\end{array}$ \\
\hline $\begin{array}{l}\text { Stuck at home with full family } \\
\text { leading to space crunch }\end{array}$ & $12 \%$ & $10 \%$ & $17 \%$ & $17 \%$ & $44 \%$ \\
\hline Anger issues within family members & $15 \%$ & $15 \%$ & $13 \%$ & $23 \%$ & $35 \%$ \\
\hline $\begin{array}{l}\text { Sharing of limited resources such as } \\
\text { space, TV, laptops, wifi connections } \\
\text { etc] }\end{array}$ & $10 \%$ & $12 \%$ & $14 \%$ & $17 \%$ & $47 \%$ \\
\hline Domestic violence & $5 \%$ & $8 \%$ & $11 \%$ & $8 \%$ & $67 \%$ \\
\hline $\begin{array}{l}\text { Increase in domestic chores due to } \\
\text { children at home at all times }\end{array}$ & $15 \%$ & $15 \%$ & $15 \%$ & $15 \%$ & $42 \%$ \\
\hline $\begin{array}{l}\text { Inability to escape constant } \\
\text { nagging/arguments by family } \\
\text { members }\end{array}$ & $11 \%$ & $5 \%$ & $21 \%$ & $20 \%$ & $43 \%$ \\
\hline Taking care of the elderly & $9 \%$ & $11 \%$ & $21 \%$ & $11 \%$ & $48 \%$ \\
\hline Average \% & $11 \%$ & $11 \%$ & $16 \%$ & $16 \%$ & $46 \%$ \\
\hline
\end{tabular}

Table 4. Factors leading to stress during COVID period: Due to family

A look at Tables 3 and 4 gives quite a clear picture of the factors responsible for the stress during the period of pandemic that females in the sample considered important (and not important). It is to be noted that on an average the factors that led to stress but did not have family as triggering factor, were considered 
'Extremely important' by almost $21 \%$ of the sample whereas this average percentage for familial factors responsible for stress was only $11 \%$. Similarly, of the factors responsible for stress outside the family the average of 'Not at all important' was $32 \%$ and those due to family was $42 \%$. This is an indication that family was not considered a stressor by most of the respondents. In addition to it, $78 \%$ of the respondents claimed that their family members were helpful to them during the period of the pandemic. Looking at the factors within the family that led to stress almost $15 \%$ of respondents found anger issues within the family and increased household chores to be very important factors.

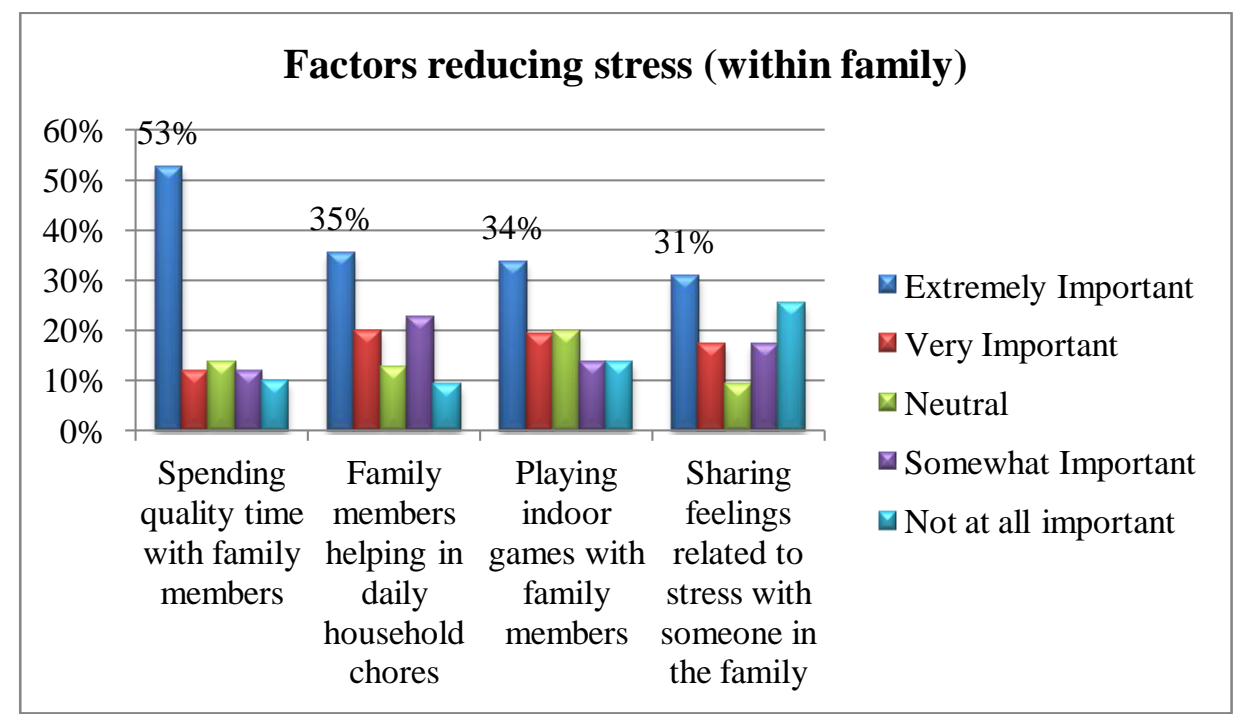

Fig 5. Factors reducing stress within the family

A look at figure 5 suggests that respondents consider almost all options provided for family reducing their stress during the pandemic to be 'Extremely important' especially spending quality time with family members (53\%). On average, 38\% respondents considered the family factors to be 'Extremely important' for reducing their stress. 


\section{Factors reducing stress (other than the family)}

Flexible work hours

Sleeping and resting for longer hours

Preparing for future by taking up online courses

Communicating with friends and relatives on phone/Internet

Exercising/meditation

Pursuing hobbies

Watching TV or other modes of entertainment

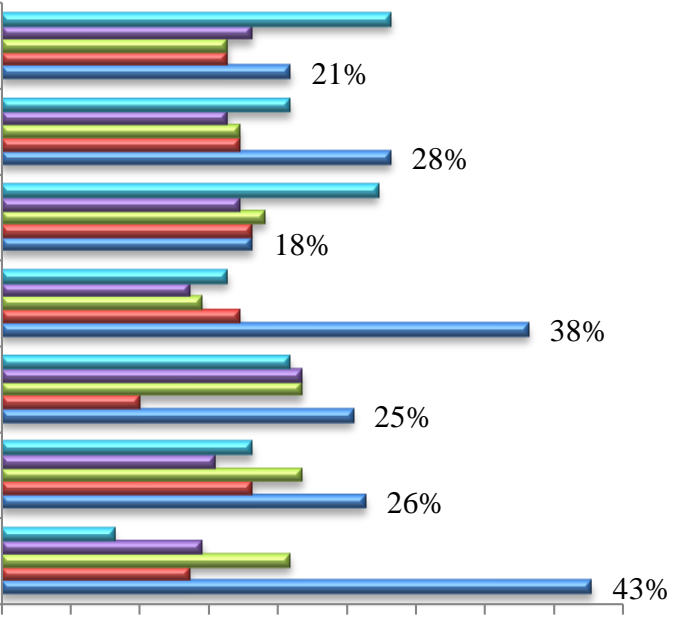

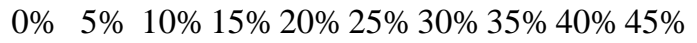

$\square$ Not at all important $\square$ Somewhat Important $\square$ Neutral

$\square$ Very Important $\square$ Extremely Important

Fig 6. Factors reducing stress (other than family)

Among the factors impacting positively upon the Indian women's lives during the pandemic other than the family factor, Watching TV or other modes of entertainment and virtual socializing with friends and relatives have been found to be extremely important factors able to reduce stress during the pandemic (Figure $6)$.

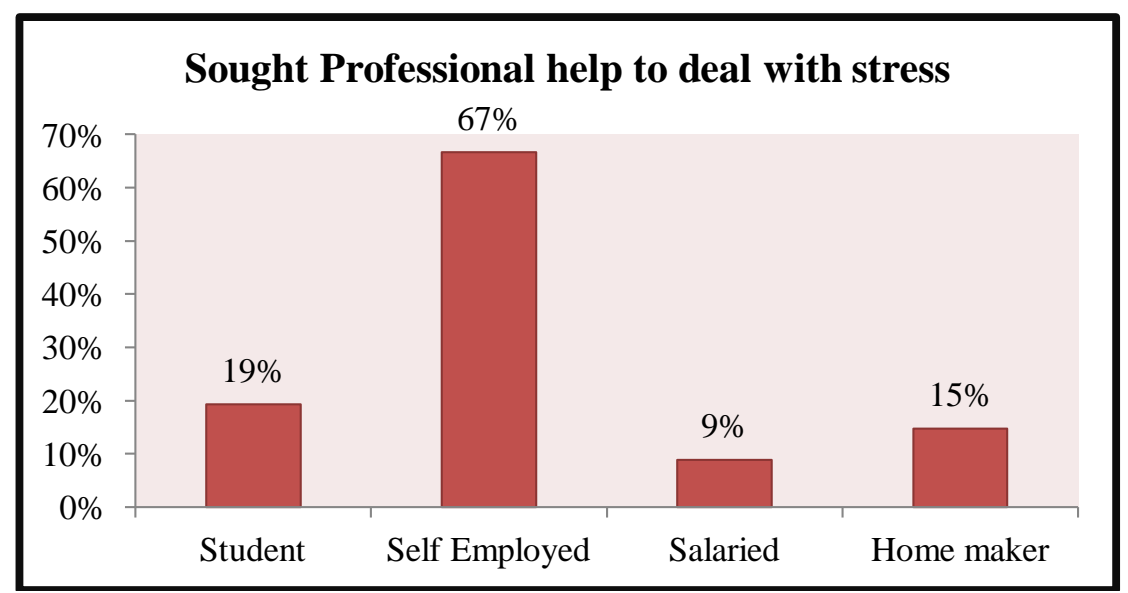

Fig 7. Professional help sought by women (Employment status-wise) 
Almost $15 \%$ of the respondents reported that the stress levels during the pandemic reached to such levels that they needed to seek professional help. Those who sought professional help belonged to various age groups. Referring to Figure 7, those who were salaried and had regular income have been found to have lesser need to reach out for professional help to deal with stress (9\%). Among those seeking professional help, self employed females $(67 \%)$ have been the most vulnerable followed by female students (19\%) and home-makers (14\%).

\section{Discussion and Conclusion}

The study reflects that during the challenging period of the pandemic, family has proved to support its female members. There have been many reports that speak of increased responsibilities and instances of domestic violence during the pandemic time, but at the same time the majority of females find support in their families rather than family being a stressor for them during the last phase of the pandemic.

The period has also seen a better sense of responsibility among the other family members as more time spent at home has brought all closer to seeing the responsibilities primarily fulfilled by the females - both as homemakers and as workers, thus family members contributing to support the lady of the house in various possible ways. During the last one and a half years of dealing with stress induced by the pandemic, although the responsibilities of the females at all fronts seem to have increased, the family has broadly emerged as a de-stressor.

\section{References and bibliography}

Chatterjee, M. 2021. "Safeguarding the Mental Health of Women of India in times of COVID 19: Challenges and ways forward" in Indian Journal of Social Psychiatry, 37(1): 3-6.

Dalal, P. K. et al. 2020. "Emerging mental health issues during the COVID-19 pandemic: An Indian perspective" ,in Indian Journal of Psychiatry, 62(9): 354-364.

Davenport, M.et al. 2020. "Moms Are Not OK: COVID-19 and Maternal Mental Health", in Frontiers in Global Women's Health. Retrieved from https://www.frontiersin.org/articles/10.3389/fgwh.2020.00001/full.

Accessed on 9 May 2021.

Jungari, S. 2020. "Maternal mental health in India during COVID-19", in Elsevier Public Health Emergency Collection. Retrieved from https://www.ncbi.nlm.nih.gov/pmc/articles/PMC7275174/ Accessed on 12 May 2021.185:97-98.

Mahapatro, M., Prasad, M. M. and Singh, S. P. 2021. "Role of Social Support in Women facing Domestic Violence during Lockdown of Covid-19 while Cohabiting with the Abusers: Analysis of Cases Registered with the Family 
Counseling Centre, Alwar, India", in Journal of Family Issues. Retrieved from https://journals.sagepub.com/doi/full/10.1177/0192513X20984496. Accessed on 12 May 2021.

Mansharamani, B. and M. Kishore, 2021. "Women's mental health and domestic violence in India during COVID-19 pandemic", in International Journal of Health and Allied Sciences, 10(1): 92-94.

Mathur, B., 2020. "Covid-19-is-causing-disruption-to-critical-mental-healthservices-world-health-orgnanisation". Retrieved from https://swachhindia. ndtv.com/covid-19-is-causing-disruption-to-critical-mental-health-servicesworld-health-orgnanisation-51323/. Accessed on 10 May 2021.

Mittal, S. and Singh, T. 2020. "Gender-Based Violence During COVID-19 Pandemic: A Mini-Review", in Frontiers in Global Women's Health, Retrieved from https://www.frontiersin.org/articles/10.3389/fgwh.2020 $.00004 / f u l l$. Accessed on 12 May 2021.

Sabharwal, D. A. 2020. "Opinion-impact-of-covid-19-pandemic-on-the-mentalhealth-of-women-and-how-they-can-deal-with-it". Retrieved from: https://swachhindia.ndtv.com/opinion-impact-of-covid-19-pandemic-onthe-mental-health-of-women-and-how-they-can-deal-with-it51541/.Accessed on 10 May 2021.

Singhania, D. 2020. "The-devastating-impact-of-the-pandemic-on-the-mentalhealth-of-women-in-india-030038439". Retrieved from https://in.makers. yahoo.com/the-devastating-impact-of-the-pandemic-on-the-mental-healthof-women-in-india-030038439.html. Accessed on 6 May 2021.

\section{The author}

Anubhuti Singh is an assistant professor associated with KES Shroff College of Arts and Commerce (an autonomous college affiliated to the University of Mumbai, India) for the last 14 years. Her fields of interest are Organizational Behaviour and Marketing. She has seven research articles published in various journals to her credit on varied topics which include Computer usage among urban elderly, Efficacy of Coaching classes in higher education, Voluntourism, Leveraging Data Analytics in Fast Food Chains and Food Delivery Platforms, Nutrition awareness among college students, Work Life Balance among women during COVID and decoding mental health of urban youth during lockdown. 